\title{
SURVEI TERPADU GAYA BERAT DAN AUDIOMAGNETOTELLURIK (AMT) DAERAH PANAS BUMI POHON BATU, KABUPATEN SERAM BAGIAN BARAT, PROVINSI MALUKU
}

\author{
Ahmad Zarkasyi, Yadi Supriyadi, Arif Munandar \\ Kelompok Penyelidikan Panas Bumi
}

\begin{abstract}
ABSTRAK
Keberadaan mata air panas bertemperatur 40-60 ${ }^{\circ} \mathrm{C}$ menjadi indikasi awal adanya sistem panas bumi di daerah Pohon Batu, Kabupaten Seram Bagian Barat, provinsi Maluku. Aplikasi metode geofisika gaya berat dan Audio Magnetotellurik (AMT) dilakukan untuk mengidentifikasi sesar geologi yang diperkirakan mengkonstruksi sistem panas bumi dan struktur tahanan jenis yang berkorelasi dengan anomali panas bumi. Jumlah titik pengukuran gaya berat sebanyak 200 titik dan AMT sebanyak 60 titik dengan desain pengukuran melingkupi area yang diperkirakan menjadi sistem panas bumi di daerah ini. Anomali gaya berat residual yang diperoleh dengan metode polinomial orde 2 memperlihatkan adanya liniasi hampir baratlauttenggara sebagai sesar yang mengontrol munculnya mata air panas. Model dua dimensi dari AMT yang diproses menggunakan algoritma Robust menunjukkan adanya anomali tahanan jenis rendah di sekitar mata air panas yang diperkirakan sebagai batuan teralterasi akibat fluida panas dan mungkin sebagai zona prospek panas bumi. Deliniasi zona prospek panas bumi diperkirakan berada di sekitar lokasi munculnya mata air panas. Lapisan batuan penudung berupa lapisan batuan bertahanan jenis $<15$ $\Omega m$ yang tersebar di sekitar manifestasi dan dibatasi oleh sesar berarah hampir utaraselatan dengan ketebalan sekitar 250-500 meter. Kedalaman puncak lapisan reservoir bertahanan jenis 30-150 $\Omega \mathrm{m}$ bervariasi yaitu sekitar kedalaman 400-700 meter. Luas daerah prospek panas bumi Pohon Batu diperkirakan sekitar $3,5 \mathrm{~km}^{2}$ dengan potensi panas bumi sekitar $15 \mathrm{MWe}$
\end{abstract}

Kata Kunci : Gaya Berat, AMT, Panas bumi, Pohon Batu

\section{PENDAHULUAN}

Secara administratif, area panas bumi Pohon Batu termasuk ke dalam wilayang Kabupaten Seram Bagian Barat, Provinsi Maluku. (Gambar 1). Kenampakan gejala panas bumi di daerah panas bumi Pohon Batu berupa sumber mata air panas yang muncul di beberapa lokasi terutama sepanjang sungai Wai Pupukula. Mata air panas tersebut bersuhu $40{ }^{\circ} \mathrm{C}-60^{\circ} \mathrm{C}$. Riset tentang kepanas bumian di daerah ini telah dilakukan sejak 2010 oleh Pusat Sumber Daya Geologi (PSDG) berupa survei pendahuluan. Pada tahun 2015, PSDG kembali melakukan survei geologi dan geokimia.

Geologi daerah Pohon Batu (Dudi, dkk, PSDG 2015) dikelompokkan (Gambar 2) menjadi satuan batuan filit (Pf), sekis (PTs), konglomerat (TQk), batugamping (Qbt), dan aluvium (Qa). Struktur geologi di daerah penyelidikan didominasi oleh struktur-struktur berarah relatif baratlaut-tenggara dan baratdayatimurlaut. Struktur sesar ini diperkirakan memfasilitasi keluarnya sejumlah mata air panas di lokasi survei.

Geokimia air panas di daerah Pohon Batu (Anna, dkk, PSDG 2015) memiliki tipe klorida-bikarbonat dan ber$\mathrm{pH}$ netral. Tipe ini mencerminkan adanya zona permeabel. Dari diagram $\mathrm{Cl}-\mathrm{Li}-\mathrm{B}$, air panas mengelompok pada zona $\mathrm{Cl}$, yang mengindikasikan air panas tersebut bisa berasal dari proses magmatik yang membawa gas $\mathrm{HCl}$ dan $\mathrm{H}_{2} \mathrm{~S}$ terlarut. Berdasarkan diagram segi tiga $\mathrm{Na} / 1000-\mathrm{K} / 100-\mathrm{Mg}^{0,5}$ mata air panas tertarik ke arah zona partial equilibrium mengindikasikan bahwa reaksi antara fluida dengan batuan

Pusat Sumber Daya Geologi

Badan Geologi - KESDM

http://psdg.bgl.esdm.go.id 


\section{Buku 1 : Bidang Energi}

Prosiding Hasil Kegiatan Pusat Sumber Daya Geologi Tahun 2015

Bandung, 11 Desember 2015

reservoir telah tercampur oleh air dingin di permukaan. Suhu reservoir untuk diperkirakan sekitar $175^{\circ} \mathrm{C}$.

Pada akhir 2015, penulis dan tim melakukan survei geofisika dengan metode gaya berat dan audio magnetotelurik atau AMT. Metode gaya berat atau graviti diharapkan dapat mengindentifikasi sesar-sesar geologi yang mengkontruksi sistem panas bumi dan juga batuan terobosan jika ada.
No : : 10

ISSN : 0261-0811
Metode AMT akan mampu mendeliniasi struktur tahanan jenis daerah ini yang mungkin berkorelasi dengan sistem panas bumi. Kombinasi hasil kedua metode geofisika diharapkan bisa menginterpretasi sistem panas bumi seperti letak, delineasi dan besarnya potensi dari keprospekan panas buminya.

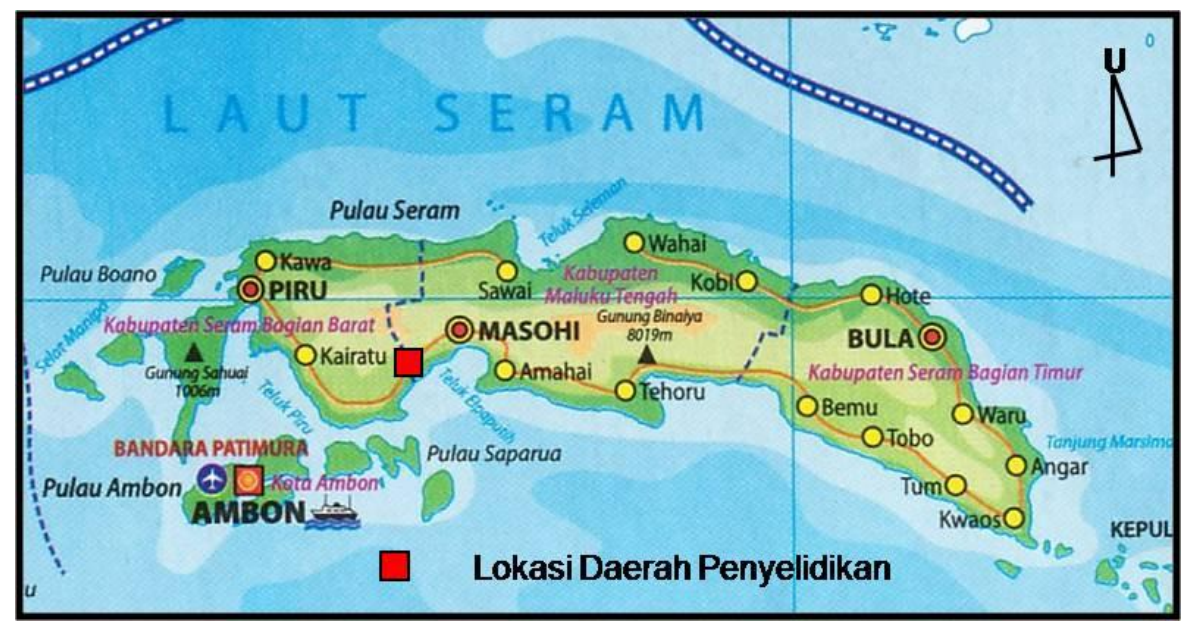

Gambar 1. Peta lokasi daerah penyelidikan

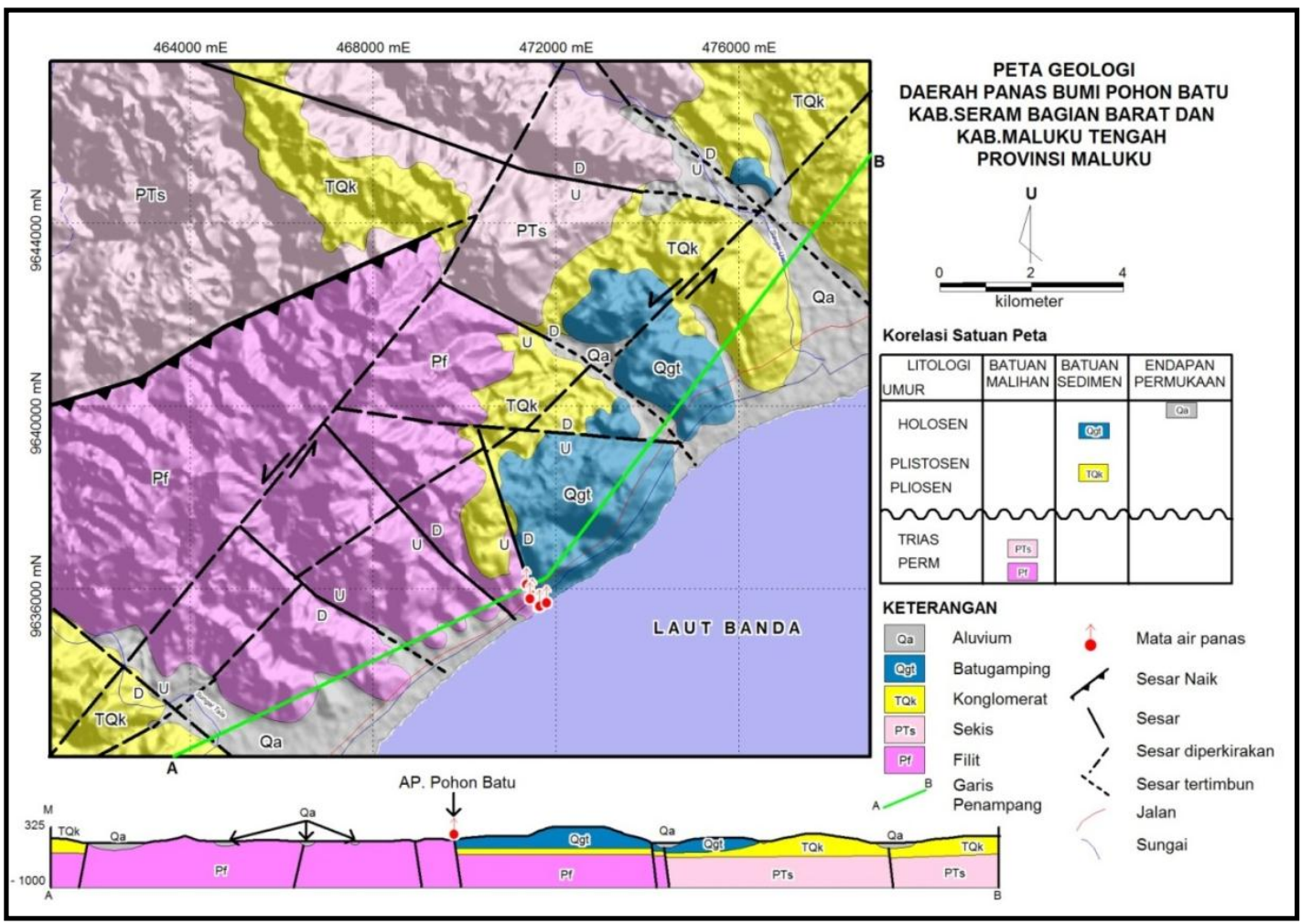

Gambar 2. Geologi daerah panas bumi Pohon Batu (Dudi, dkk, 2015)

Pusat Sumber Daya Geologi

Badan Geologi - KESDM

http://psdg.bgl.esdm.go.id 


\section{METODE DAN TEORI}

Metode geofisika yang digunakan yaitu metode gaya berat dan audiomagnetotellurik (AMT). Metode gaya berat digunakan untuk mencari informasi bawah permukaan berdasarkan variasi dari nilai densitas batuan sedangkan metode AMT berdasarkan variasi nilai tahanan jenis batuan. Kedua metode tersebut diharapkan dapat memberikan gambaran mengenai struktur bawah permukaan yang berhubungan dengan sistem panas bumi.

\section{a) Gaya Berat}

Metode ini adalah metode yang memanfaatkan medan potensial yang didasarkan pada perbedaan gaya gravitasi akibat adanya perbedaan densitas batuan di bawah permukaan.

Pengukuran titik gaya berat dilakukan dengan metode poligon tertutup, artinya mengukur di suatu titik kemudian dilanjutkan ke titik lainnya dan kembali mengukur di titik awal. Titik awal dan akhir tersebut pada penyelidikan gaya berat disebut dengan stasiun basis/base station (BS).

Data yang didapat dalam pengukuran kemudian dikoreksi untuk mendapatkan nilai anomali bouguer. Anomali bouguer adalah anomali gaya berat yang telah mengalami koreksi waktu (drift, tidal), koreksi topografi (Bouguer, udara bebas, terrain) dan koreksi gaya berat normal. Kemudian anomali bouguer tersebut di-filter untuk mendapakan anomali regional dan residual.

Pemodelan data gaya berat dilakukan dengan menggunakan inversi 2,5 dimensi.

\section{b) AMT}

\section{Metode ini memanfaatkan} medan elektromagnet alam pada rentang frekuensi $0.1-10000 \mathrm{~Hz}$. Medan EM (medan magnet dan medan

Pusat Sumber Daya Geologi

Badan Geologi - KESDM

http://psdg.bgl.esdm.go.id listrik) diukur secara bersamaan pada rentang waktu tertentu. Hubungan antara medan listrik dan medan magnet tersebut menghasilkan nilai tahanan jenis semu dan phase.

Nilai tahanan jenis semu dihitung berdasarkan perbandingan antara medan listrik dan medan magnet yang dikenal dengan persamaan Cagniard, yang dihasilkan dari persamaan Maxwell dengan asumsi gelombang bidang. Tahanan jenis semu terdiri dari dua buah kurva, yaitu kurva Rho-xy dan kurva Rho-yx.

Pengukuran titik AMT dilakukan pada titik-titik ukur yang telah ditentukan. Kemudian dilakukan setting pengukuran dan setelah siap baru dilakukan pengukuran data. Pengukuran data dilakukan dengan tiga band, band 1 dengan range frekuensi antara 256$8192 \mathrm{~Hz}$, band 2 dengan range frekuensi 3-192 $\mathrm{Hz}$ dan band 3 dengan range frekuensi $0.09-8 \mathrm{~Hz}$. Setelah data tersebut diperoleh, kemudian dilakukan quality control (QC) dengan menggunakan perangkat lunak MTEditor. Kemudian jika dirasa sudah bagus datanya, kemudian dilakukan pemodelan data menggunakan perangkat lunak WinGLink untuk mendapatkan model penampang 2D dan sebaran tahanan jenis pada berbagai kedalaman.

\section{HASIL PENYELIDIKAN}

\section{A. Gaya Berat}

Pengukuran titik gaya berat di daerah Pohon Batu dilakukan menggunakan peralatan Scintrex dengan serial number alat 40694. Jumlah titik pengukuran gaya berat sebanyak 200 titik dengan menggunakan metode pengukuran sistem tertutup (looping). Posisi stasion basis (BS) berada di basecamp dengan posisi geografis pada $128^{\circ} 43^{\prime} 14.0222^{\prime \prime}$ LS dan -3'18'45.1553" LU dengan ketinggian $15 \mathrm{~m}$ dpl.

Analisis hasil laboratorium memperlihatkan densitas dari tiga jenis 
batuan yang menyusun daerah Pohon Batu. Batuan metamorf/skis yang dominan menunjukkan densitas sebesar 2,7 $\mathrm{gr} / \mathrm{cm}^{3}$. Jika hasil laboratorium dirata-ratakan menghasilkan densitas $2,37 \mathrm{gr} / \mathrm{cm}^{3}$. Sedangkan hasil metode parasnis, memperlihatkan densitas batuan sekitar 2,28 $\mathrm{gr} / \mathrm{cm}^{3}$. Hasil komparasi anomali Bouguer (CBA) tidak begitu signifikan. Berdasarkan ketiga analisis tersebut maka densitas dipilih mengikuti pendekatan nilai hasil laboratorium yaitu sekitar $2,3 \mathrm{gr} / \mathrm{cm}^{3}$.

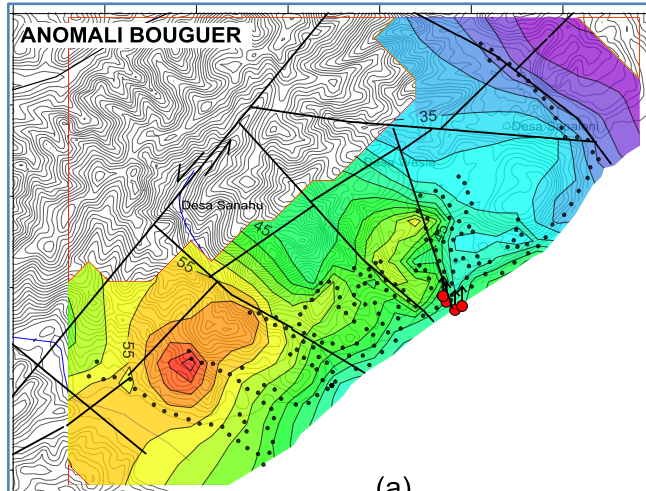

(a)

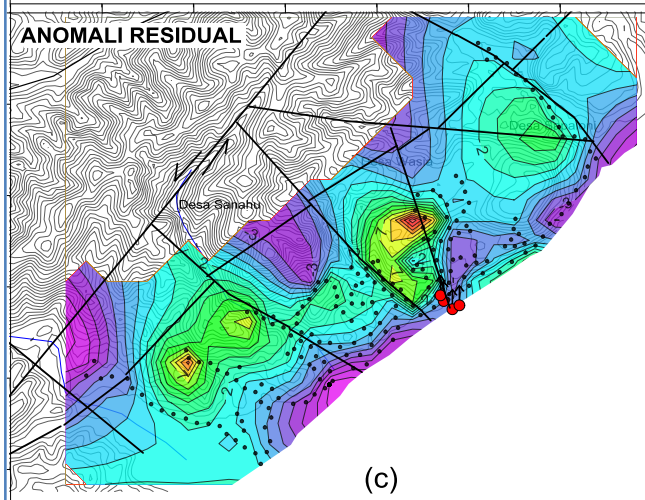

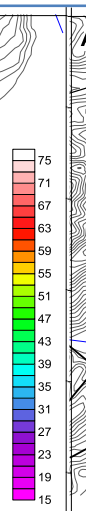
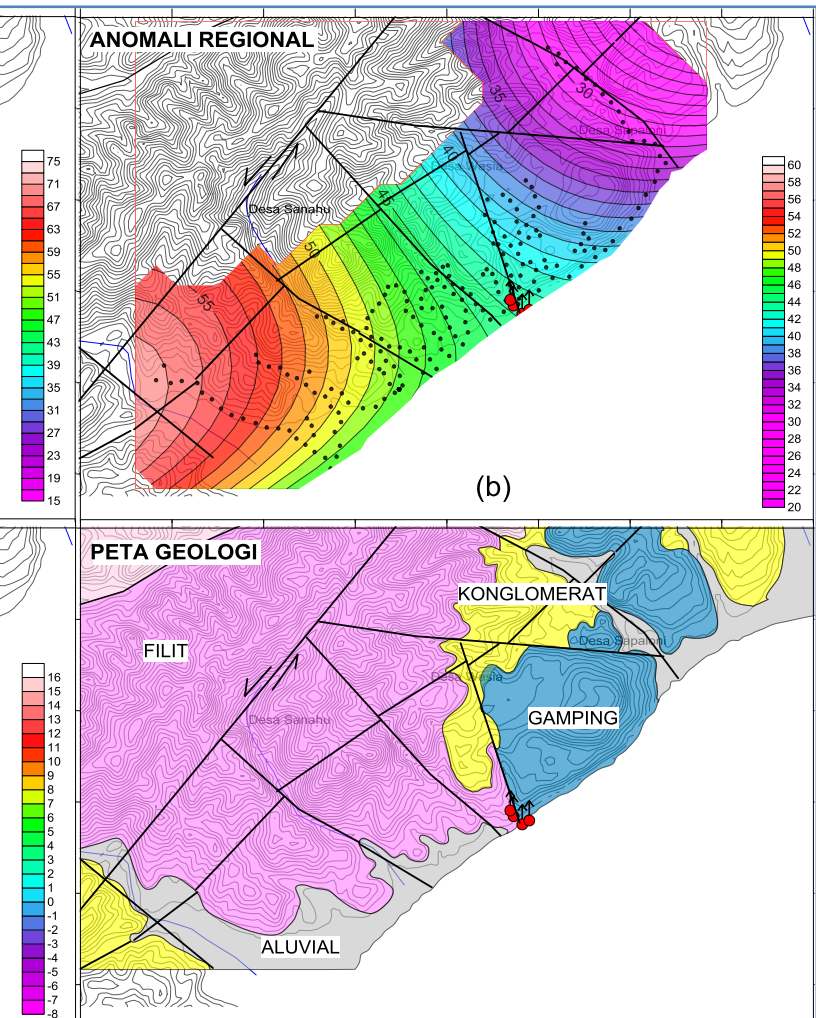

Gambar 3. Anomali Bouguer (a), regional (b), residual (c)

Nilai anomali Bouguer berkisar antara 24-66 mGal (Gambar 3a). Pola sebaran anomali cenderung bernilai tinggi di sisi baratdaya dan bernilai rendah di timurlaut dengan liniasi kontur berarah berarah baratlaut-tenggara dan baratdaya-timurlaut. Pembelokan terjadi di bagian tengah sekitar manifestasi air panas dan terdapat anomali yang tinggi (>50 mGal) dengan pola tertutup. Anomali tinggi di lokasi manifestasi panas bumi mengindikasikan blok batuan berdensitas tinggi..

Liniasi kontur berarah baratdayatimurlaut terlihat di sepanjang garis pantas dan bagian tengah di area perbukitan. Liniasi ini diperkirakan merupakan struktur besar dengan arah yang sama. Sedangkan liniasi-liniasi berarah baratlaut-tenggara yang muncul di sela-sela bagian tengah diperkirakan sebagai sesar geologi dengan arah yang sama dan merupakan sesar sekunder atau lebih muda dari sesar berarah baratdaya-timurlaut.

Gambar 3b memperlihatkan peta anomali regional yang diperoleh dari pemisahan CBA dengan menggunakan metode polinomial orde 3 . Nilai anomali regional memiliki rentang 22-58 mGal. Pola anomali regional memilki kecenderungan tinggi di bagian baratdaya dan merendah secara gradasi ke arah timurlaut dengan liniasi berarah baratlaut-tenggara dan baratdayatimurlaut. Nilai tinggi di bagian baratdaya mengindikasikan struktur batuan dasar di area bagian baratdaya

Pusat Sumber Daya Geologi

Badan Geologi - KESDM

http://psdg.bgl.esdm.go.id 
lebih masif dan berdensitas lebih tinggi dibandingkan penyusun batuan di bagian timurlaut. Liniasi kontur berarah baratdaya-timurlaut mengindikasikan sesar dengan arah yang sama dan liniasi baratlaut-tenggara di bagian tengah mengindikasikan arah struktur sesar sekundernya.

Gambar 3c memperlihatkan peta anomali residual daerah Pohon Batu Rentang nilai anomali diperoleh sekitar 8 - 13 mGal. Pola umum anomali residual mengindikasikan blok batuan di sisi perbukitan bagian tengah ke arah baratdaya memiliki densitas yang lebih tinggi dibandingkan dengan bagian tengah ke timurlaut. Jika dikorelasikan dengan batuan penyusun daerah ini, maka diperkirakan anomali tinggi di sisi baratdaya adalah batuan metamorf dan di sisi timurlaut adalah konglomerat dan gamping. Terdapat spot anomali tinggi yang muncul di utara lokasi mata air panas dengan nilai $>8 \mathrm{mGal}$. Interpretasi anomali tinggi di lokasi tersebut masih harus di korelasikan dengan lingkungan geologi sekitarnya.

\section{B. Audiomagnetotellurik (AMT)}

Jumlah titik pengukuran AMT sebanyak 60 titik ukur dengan jarak antar titik ukur sekitar 250-750 meter. Kualitas data yang diperoleh mayoritas cukup bagus dengan rentang frekuensi $8000-1 \mathrm{~Hz}$. Proses pengolahan data AMT secara umum meliputi: konversi data time series ke domain frekuensi, kontrol kualitas data, pengeditan data, konversi data ke format EDI, rotasi data, pengeditan file EDI, koreksi static effect dan pemodelan. Koreksi efek statik yang digunakan adalah metode statistik.

Sebaran model tahanan jenis dari hasil inversi 2D diperlihatkan pada Error! Reference source not found.4 Tahanan jenis bernilai rendah menjadi anomali menarik dalam sistem panas bumi. Nilai tahanan jenis rendah diperkirakan berkorelasi dengan batuan teralterasi akibat kontak dengan fluida panas. Fluida panas di daerah Pohon

Pusat Sumber Daya Geologi

Badan Geologi - KESDM

http://psdg.bgl.esdm.go.id
Batu dicirikan dengan adanya manifestasi berupa mata air panas.

Sebaran tahanan jenis di daerah Pohon Batu terpola mulai dari kedalaman terdangkal (250 meter) sampai dengan sayatan terdalam (1500 meter). Tahanan jenis tinggi mayoritas berada di bagian tengah dan sisi baratdaya. Nilai tahanan jenis relatif tinggi/sedang mengisi area bagian timur dan timurlaut. Sedangkan nilai tahanan jenis rendah muncul dengan pola spot di sekitar mata air panas.

Nilai tahanan jenis tinggi di tengah dan barat daya (>250 $\Omega \mathrm{m})$ diperkirakan respon batuan metamorf berupa filit yang menyusun area perbukitan. Area tengah-timurlaut yang tersusun oleh batu gamping dan konglomerat direspon oleh nilai tahanan jenis sedang $(50-150 \Omega m)$ sampai dengan tinggi (>200 $\Omega \mathrm{m})$. Daerah sekitar mata air panas ditempati oleh tahanan jenis yang rendah dengan nilai $<25 \Omega$ m

Pola sebaran yang terbentuk konsisten sampai ke kedalaman. Daerah perbukitan berbatuan filit memiliki tahanan jenis 200-400 $\Omega \mathrm{m}$ mulai dari kedalaman 250-500 meter dan semakin tinggi nilai tahanan jenisnya dengan bertambahnya kedalaman $(>750 \Omega \mathrm{m})$. Pertambahan nilai tahanan jenis ini sebagai indikasi batuan yang lebih segar dan masif dibandingkan batuan di permukaan.

Luasan area bertahanan jenis rendah $(<25 \Omega \mathrm{m})$ di lokasi mata air panas mengalami perubahan dengan bertambahnya kedalaman. Pada kedalaman 250 meter berbentuk spot tertutup, kemudian bertambah luas pada kedalaman 500 dan 750 meter. Pada kedalaman 1000 meter luas area bertahanan jenis rendah ini kembali mengecil bahkan tidak ditemukan lagi pada kedalaman 1250 meter.

Perubahan tahanan jenis di area mata air panas ini kemungkinan pengaruh fluida panas. Nilai tahanan jenis rendah yang muncul diperkirakan akibat batuan teralterasi. Luasan area 
batuan bertahanan jenis rendah juga mengindikasikan kuantitas/intesitas batuan ubahannya. Pada kedalaman $>1000$ meter sudah tidak terdapat lagi anomali tahanan jenis rendah yang diasumsikan fluida panas sudah tidak lagi mempengaruhi batuan sekitarnya.

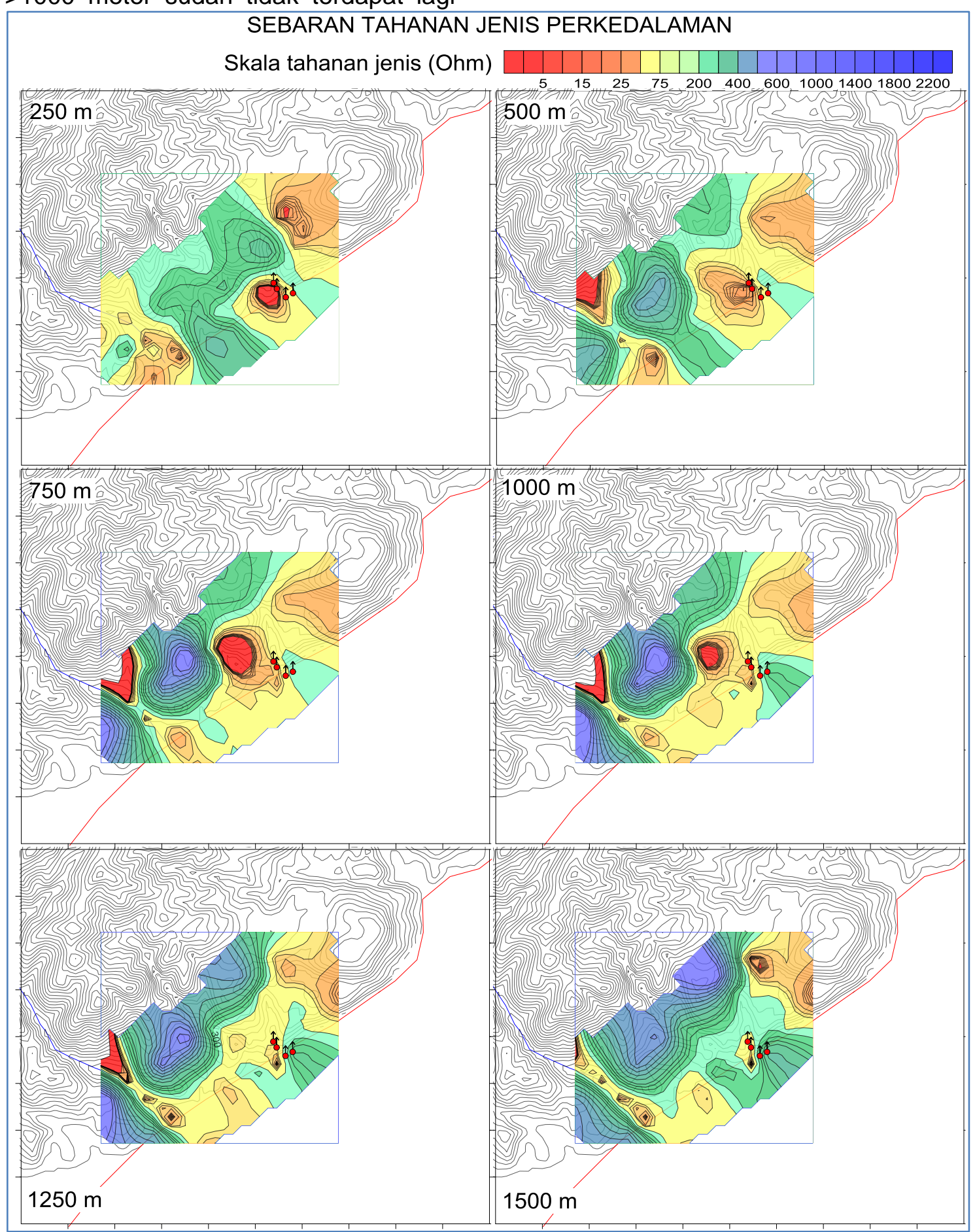

Gambar 4 Sebaran tahanan jenis per kedalaman daerah panas bumi Pohon Batu

\section{PEMBAHASAN}

Pusat Sumber Daya Geologi

Badan Geologi - KESDM

http://psdg.bgl.esdm.go.id
Anomali gaya berat (Bouguer) memperlihatkan nilai anomali di sisi 
baratdaya lebih tinggi dibandingkan sisi timurlaut. Tren anomali ini menunjukkan area tersebut berdensitas lebih tinggi yang secara permukaan berupa batuan metamorf (filit) sedangkan sisi timurlaut tersusun dari batugamping dan konglomerat.

Liniasi kontur anomali Bouguer juga selaras dengan arah sesar yang berkembang. Pola liniasi anomali Bouguer cendrung dominan baratdayatimurlaut yang selaras dengan sesar geologi. Liniasi anomali di bagian tengah berarah baratlaut-tenggara dan diperkirakan merupakan cerminan sesar sekunder atau sesar yang aktif setelah sesar baratdaya-timurlaut. Anomali regional sendiri menunjukkan bahwa nilai di sisi baratdaya lebih tinggi. Sedangkan arah liniasi dari anomali regional hanya mencerminkan arah sesar sekunder, yaitu sesar berarah baratdaya-timurlaut. Anomali residual memperjelas bahwa blok batuan di sisi perbukitan bagian tengah ke arah baratdaya memiliki densitas yang lebih tinggi dibandingkan dengan bagian tengah ke timurlaut.
Anomali yang menarik adalah spot anomali tinggi yang muncul di utara lokasi mata air panas. Keberadaan anomali ini jika diinterpretasi adanya aktivitas plutonisme maka di bawah permukaan dari lokasi tersebutlah diperkirakan aktivitas tersebut. batuan plutonik itu pula yang diduga sebagai sumber panas yang energinya ditransfer secara konduktif dan konvektif pada reservoir.

berupa batuan teralterasi dan diindikasikan dengan nilai tahanan jenis rendah. Pada penampang tahanan jenis (Gambar 5) terlihat adanya lapisan batuan bertahanan jenis rendah dengan nilai $<15 \mathrm{Ohmm}$ yang diinterpretasikan sebagai lapisan batuan teralterasi yang berfungsi sebagai lapisan penudung. Di bawah lapisan batuan teralterasi ini terdapat lapisan batuan bertahanan jenis tinggi dengan nilai sekitar 30-150 Ohmm yang diduga sebagai zona reservoir. Zona transisi antara lapisan penudung dan resevoir merupakan top reservoir yang kedalamannya bervariasi sekitar 400 sampai dengan 700 meter.

Pusat Sumber Daya Geologi

Badan Geologi - KESDM

http://psdg.bgl.esdm.go.id 


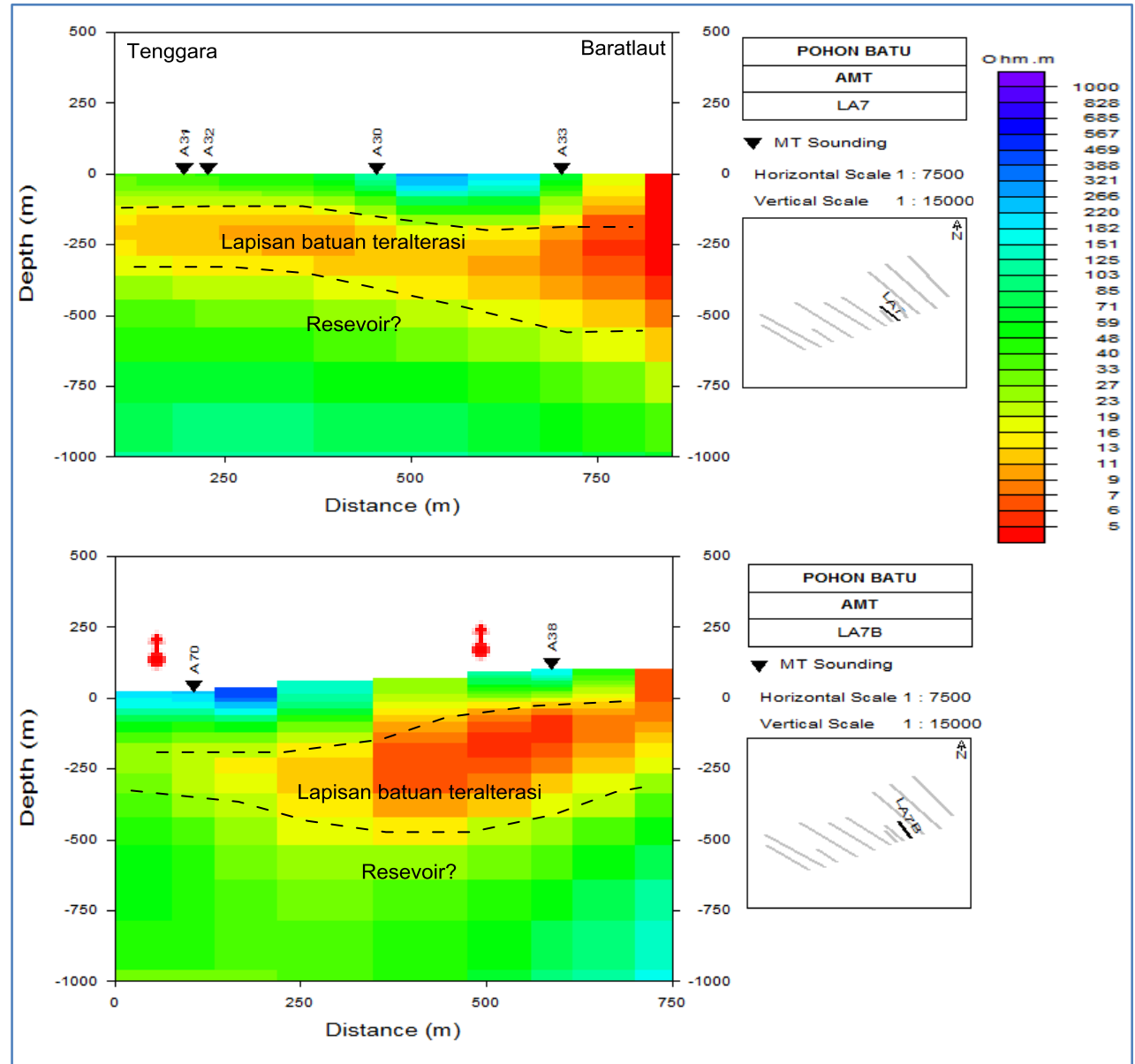

Gambar 5 Penampang tahanan jenis lintasan LA7 dan LA7B

Prospek panas bumi Pohon Batu dikompilasi dari metode geofisika, geologi dan geokimia diperkirakan berada di sekitar manifestasi mata air panas Pohon Batu (Gambar 6). Area prospek ini tersebar sepanjang struktur berarah utara- selatan. Metode kimia mendukung area prospek ini dari hasil anomali $\mathrm{Hg}$ dan $\mathrm{CO}_{2}$ yang tinggi. Metode geologi mendukung dengan keberadaan manifestasi panas bumi dan pola struktur geologi.
Metode

geofisika memperlihatkan adanya anomali tahanan jenis rendah dan anomaly gaya berat tinggi. Kompilasi semua metode tersebut diperoleh luas zona prospek panas bumi Pohon Batu sekitar 3,5 km². Potensi panas bumi di daerah ini dengan luas sekitar $3,5 \mathrm{~km}^{2}$, temperatur reservoir sebesar $175^{\circ} \mathrm{C}$ maka dengan menggunakan metode penghitungan volumetrik adalah sebesar 15 Mwe (Tabel 1).

Pusat Sumber Daya Geologi

Badan Geologi - KESDM

http://psdg.bgl.esdm.go.id 


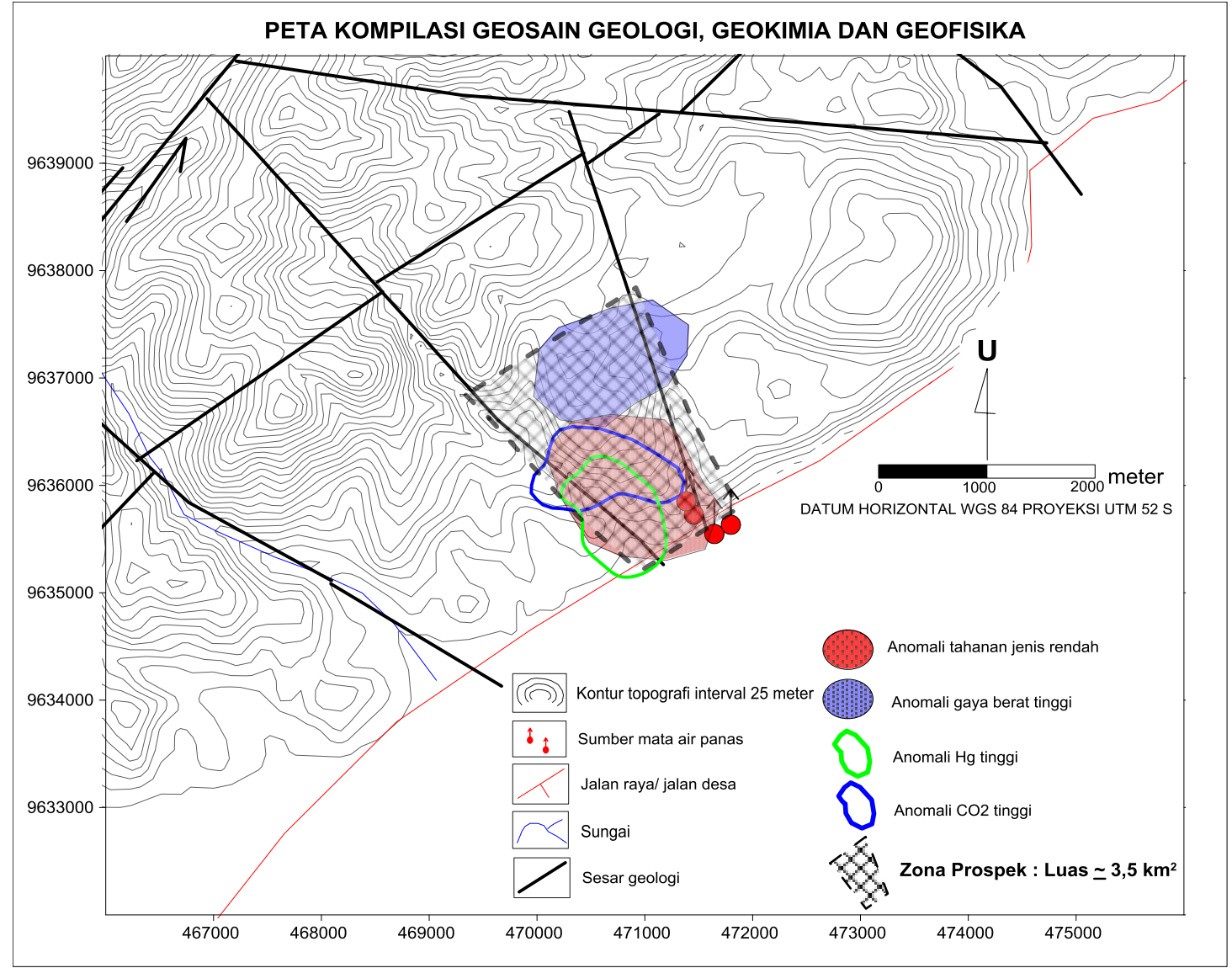

Gambar 6 kompilasi geosain dan keprospekan

Tabel 1 Penghitungan potensi panas bumi

Pusat Sumber Daya Geologi

Badan Geologi - KESDM

http://psdg.bgl.esdm.go.id 


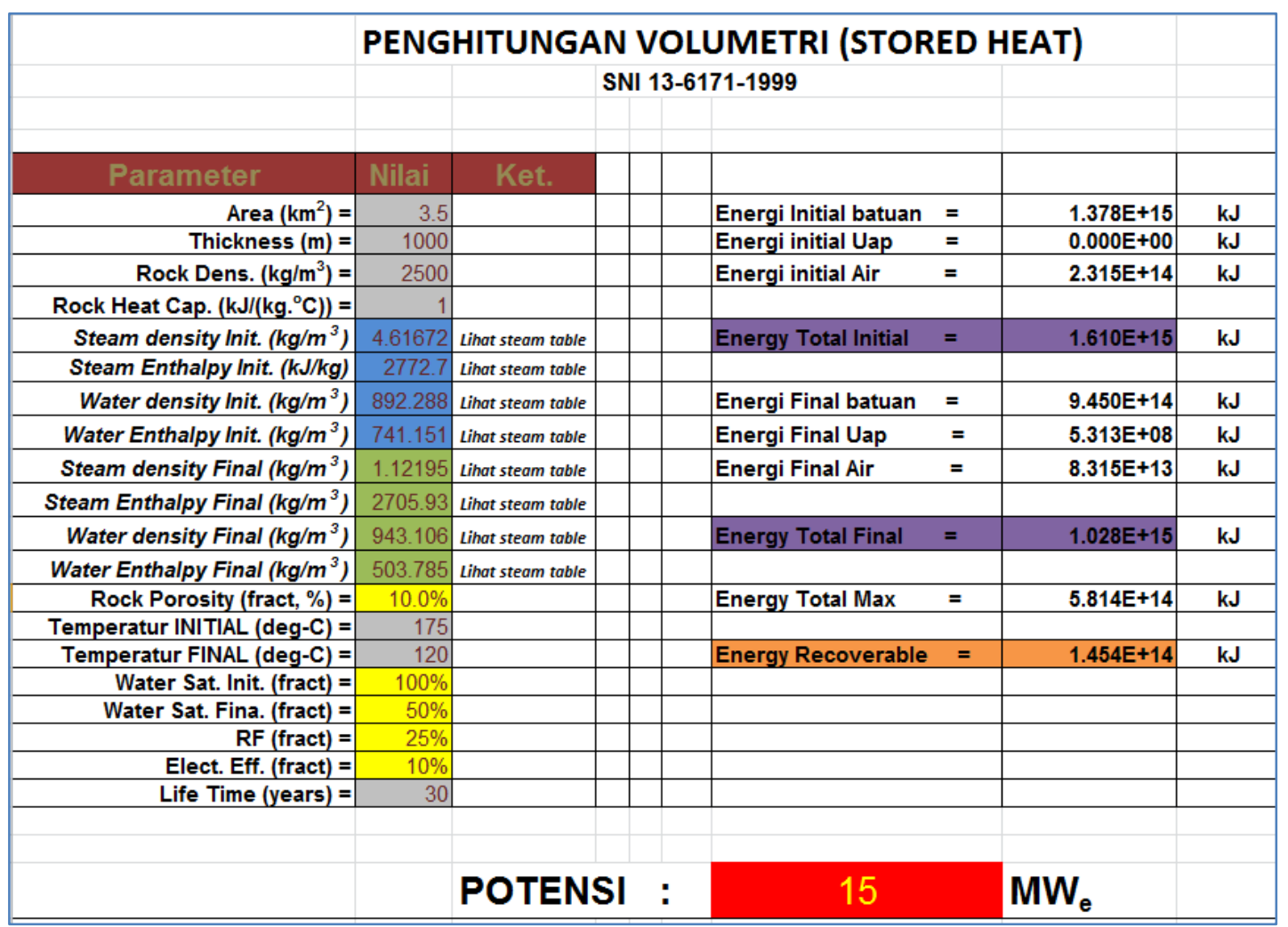

\section{KESIMPULAN}

Daerah prospek panas bumi Pohon Batu berada di sekitar lokasi munculnya mata air panas. Sistem panas bumi yang terbentuk diperkirakan karena adanya sisa panas dari batuan plutonik yang diindikasikan dengan gaya berat tinggi di sekitar manifestasi.

Lapisan batuan penudung diperkirakan tersusun dari batuan bertahanan jenis $<15$ Ohmm yang tersebar di sekitar manifestasi dan dibatasi oleh sesar berarah hampir utara-selatan. Ketebalan lapisan penudung diperkirakan sekitar 250-500

\section{DAFTAR PUSTAKA}

Badan Standardisasi Nasional, 2000., Angka Parameter Dalam Estimasi Potensi energi panas bumi, SNI 13- 6482- 2000.

Burger, H.R., 1992: Exploration Geophysics of shallow Sub Surface, Prentice Hall

Kadir, W.G.A., 2000, Eksplorasi Gaya Berat dan Magnetik, Jurusan meter. Lapisan resevoir mulai terdeteksi pada kedalaman sekitar 400-700 meter dengan nilai tahanan jenis 30-150 Ohmm. Luas daerah prospek panas bumi Pohon Batu diperkirakan sekitar $3,5 \mathrm{~km}^{2}$ dan potensi panas bumi sekitar $15 \mathrm{MWe}$

\section{UCAPAN TERIMA KASIH}

Ucapan terima kasih tim penulis hantarkan kepada para staff Pusat Sumber Daya Geologi bidang panas bumi yang telah berperan serta dalam penulisan makalah ini.

Teknik Geofisika, Fakultas IImu Kebumian dan Teknologi Mineral, Institut Teknologi Bandung

Lawless, J., 1995. Guidebook: An Introduction to Geothermal System. Short course. Unocal Ltd. Jakarta.

Noya, Y, dan Kusumadinata (1991): Peta Geologi Regional Lembar Pantar dan Wetar, Pusat Penelitian dan

Pusat Sumber Daya Geologi

Badan Geologi - KESDM

http://psdg.bgl.esdm.go.id 


\section{Pengembangan Geologi, Bandung, 1991. \\ Inventarisasi Sumber daya Mineral Bandung.}

Telford, W.M. et al, 1982. Applied Geophysics.

Cambridge University Press. Cambridge.

Tim Inventarisasi, (2001), Penyelidikan Pendahuluan Geologi dan Geokimia Potensi Panas Bumi, di Pulau Pantar, Direktorat
Tim Survei Terpadu Geologi dan Geokimia. 2015. Survei Terpadu Geologi dan Geokimia Panas Pumi Daerah Pantar Kabupaten Alor,Provinsi Nusa Tenggara Timur. Pusat Sumber Daya Geologi 